\title{
Impact of Banking Statutes, Housing-Market, Economic, and Financial Conditions on Bank Failures in the U.S, 1970-2008: GARCH Estimates
}

\author{
Richard J. Cebula \\ Davis College of Business, Jacksonville University \\ Jacksonville, FL, USA 32211 \\ Tel: +1-904-379-8086Ｅ-mail: rcebula@ju.edu
}

Received: January 10, 2010 Accepted: February 7, 2010 doi:10.5430/ijfr.v2n1p23

\begin{abstract}
Bank solvency questions and bank failures in the U.S. have become issues of renewed concern in recent years. Given the significance of bank solvency and bank failures for the health and stability of the U.S. economy, it is imperative to have insights into those factors that systematically influence bank failures. Accordingly, this empirical study seeks to identify those factors influencing the bank failure rate in the U.S. over the period 1970 through 2008, with emphasis on: (1) recent major banking statutes, including: the Community Reinvestment Act of 1977, CRA, the Federal Deposit Insurance Corporation Improvement Act of 1991, FDICIA, the Riegle-Neal Interstate Banking and Branching Efficiency Act of 1994, RNIBA, and the Gramm-Leach-Bliley Act, GLB Act; (2) the health of the housing market; and (3) general economic and financial market conditions. The GARCH estimates indicate that FDICIA acted to reduce bank failures, whereas (presumably by increasing competition and/or increasing costs through branch bank expansion) RNIBA induced a net increase in bank failures in the U.S. The GARCH evidence implies that the CRA also led to increased bank failures in the U.S., arguably by exposing banks to greater credit risk. The evidence also indicates that the GLB Act may also have acted to induce more bank failures. Furthermore, a stronger housing market was found to reduce bank failures, whereas a stronger economy as well as more favorable interest rate conditions reduced bank failures.
\end{abstract}

Keywords: Bank failures, Banking legislation, Housing market, Financial conditions

\section{Introduction}

Questions regarding bank solvency and bank failures in the U.S. have become issues of renewed concern in recent years, especially in view of the "Great Recession." In this context, it is noteworthy that not since the years of the Great Depression had the U.S. government regulatory authorities closed so many banks as they did during the 1980s and early 1990s. For the period from 1943 through 1981, relatively few banks were closed because of insolvency. However, this situation changed dramatically beginning with the year 1982, during which 42 banks were closed, followed by 48 closings in 1983 and 79 closings in 1984. The number of closed banks increased sharply thereafter, surpassing 100 closings annually through the early 1990s. Indeed, the bank closing rate did not decline significantly until after the implementation of the provisions of FDICIA, the Federal Deposit Insurance Corporation Improvement Act of 1991 (Benston \& Kaufman, 1997; Cebula, 1996, 1999).

Unfortunately, beginning in 1998 and 1999, the bank failure rate in the U.S. began to climb again. Given the significance of bank failures for the overall health and stability of the economy, this increased bank failure rate is problematic, as reflected in the arguably rather Draconian "bailout" measures undertaken during 2008 by the Bush Administration and under the Obama Administration in 2009, measures ostensibly undertaken in part under the doctrine of TLTF (too large to fail). Indeed, it would seem appropriate to revisit the issue and attempt to identify key factors, including federal banking statutes such as the CRA (Community Reinvestment Act of 1977, revised and enhanced in 1995), FDICIA (the Federal Deposit Insurance Corporation Improvement Act of 1991), and RNIBA (The Riegle-Neal Interstate Banking andBranching Efficiency Act of 1994) statutes that may have influenced bank failures in the U.S., not only in the latter part of the 20th century but in more recent years since 2000 as well. Moreover, the impact of the Gramm-Leach-Bliley (GLB) Act, which has recently been examined, albeit briefly (Cebula, 2010), also warrants further consideration.

Interestingly, research on the effects of banking legislation on bank performance has been limited in volume and typically (although certainly authoritative) either largely descriptive and analytical in nature (Apgar \&Duda, 2003; Avery, Bostic, \& Canner, 2000; Barth, 1991, 2009; Barth, Brumbaugh, \& Litan, 1992; Benston \& Kaufman, 1997) or empirically analyzed merely using OLS, i.e., ordinary least squares (Cebula, 1996, 1999, 2010; Wheelock \& Wilson, 
2000; Cebula, Koch, \& Fenili, 2011). The present study is the first to use GARCH empirical estimation in the context of identifying bank failure determinants.

Accordingly, the purpose of this empirical study is to identify, using GARCH estimations, key economic, financial-market, housing-market, and statutory determinants of U.S. bank failures for the period 1970 through 2008. Section II of this study provides the basic model. The empirical results in the form of GARCH estimations are provided and discussed in Section III of the study. Section IV provides the study conclusions.

\section{An Eclectic Model}

For purposes of this study, a bank failure occurs when a bank is forced by regulators either to close or to merge with another banking institution. This study adopts an eclectic model of bank failure determinants in the aggregate. This eclectic perspective is based largely on the findings and observations in previous related studies (Amos, 1992; Barth et al., 1992; Benston \& Kaufman, 1997; Cebula, 1996; Chao \& Cebula, 1996; Loucks, 1994; Saltz, 1994; Wheelock \& Wilson, 2000; Gropp, Vesala, \& Vulpes, 2006). In particular, most of these studies have empirically investigated models that are fundamentally eclectic in nature, presumably reflecting the observations made in these studies that the causes of bank failures at the aggregate level are rather diverse. To the extent that that is true, a myopically based model is unlikely to provide useful insights into bank failures at the aggregate level. However, the model and analysis differ from most prior studies in at least the following two ways: (a) the study period runs through the year 2008 and thus is more current; and (b) it accounts explicitly for the impact not only of FDICIA, as in Cebula $(1996,1999)$ and Benston \& Kaufman (1997), but also for the potential impacts of the CRA and the RNIBA, as well as the GLB Act. Moreover, this is the first study to apply the GARCH estimation technique to the problem under consideration in this study.

To begin, this study follows several earlier related studies (Amos, 1992; Barth et al., 1992; Cebula, 1996; Loucks, 1994; Saltz, 1994, Wheelock \& Wilson, 2000) by including economic/financial variables. These variables include the percentage growth rate of real GDP (Y) and the unemployment rate of the civilian labor force (UR), which are adopted in order to reflect the overall performance of the economy. The stronger the performance of the economy, as reflected in this study by a higher value of $Y$ and a lower value of UR, the better the performance of bank loan portfolios and, as a result, the lower the likelihood of bank failures (Amos, 1992; Barth, 1991; Barth et al., 1992; Loucks, 1994). Next, the higher the cost of funds for banks (COST), the lower bank profitability and over time the greater the probability of bank failures (Bradley and Jansen, 1986, Barth, 1991; Barth \& Brumbaugh, 1992; Barth et al., 1992; Loucks, 1994; Saltz, 1994), ceteris paribus. The last of the economic/financial variables initially considered is the interest rate yield on new 30 year fixed-rate home mortgages (MORT). Banks have been active in financing real estate mortgages, including those of the 30 year fixed-rate variety, and in so doing obviously financially benefit when the interest rate yield on these new home mortgages is higher, ceteris paribus. There are at least two reasons for this. First, for the period over which the bank holds the mortgage, the higher the MORT level, the greater the profitability of mortgages (Bradley \& Jansen, 1986; Cebula \& Belton, 1994; Loucks, 1994). Second, the higher the MORT level, the higher the price banks can extract when selling the mortgage in question on the secondary market (Madura, 2008, pp. 207-208). Thus, it is expected that the bank failure rate is inversely a function of MORT (Bradley \& Jansen, 1986; Barth et al., 1992; Loucks, 1994; Madura, 2008; Saltz, 1994), ceteris paribus. Next, there is the case of the structural federal budget deficit, DEFY, expressed as a percent of GDP. The greater the value of DEFY, in theory, the more expansionary fiscal policy is and hence the stronger the economy; therefore, the higher the DEFY level, ceteris paribus, the lower the incidence of bank failures should be. Finally, there is the case of the number of new home sales per capita, HOMESPC. The higher this value, the greater the demand for bank services and hence the more prosperous banks should be (Barth, 2009), ceteris paribus.

Given the economic, financial-market, and housing-market variables provided above, this study seeks also to investigate initially the impacts of three federal banking statutes. These statutes are the Community Reinvestment Act of 1977 (revised and enhanced in 1995), CRA; the Federal Deposit Insurance Corporation Improvement Act of 1991, FDICIA; and the Riegle-Neal Interstate Banking and Branching Efficiency Act of 1994, RNIBA. It is observed that the Gramm-Leach-Bliley GLB Act (1999) is considered formally in this study as well, but in the subsequent GARCH estimate, which is intended in part as a test of the robustness of the basic model.

The practice of "redlining" served as a de facto means of controlling credit risk. To illustrate, consider two neighborhoods, A and B, each of which offers a variety of loan opportunities. Banks will extend loans in both A and B until, holding the interest rate and other relevant factors constant, the perceived riskiness of loans made to the two neighborhoods is at the margin equal. In this fashion, banks control their credit risk. However, if one neighborhood, say A, provides predominantly or solely high-risk lending opportunities, the banks will direct all or nearly all of their lending to the low-risk neighborhood, B. The bank would in effect have drawn a red line around the high-risk community, A, to which it extends few if any loans. 
The Community Reinvestment Act of 1977 sought to require that banks meet the credit needs of qualified borrowers in their communities, i.e., in the geographic areas in which they operate and accept deposits, even those would-be borrowers that have low or moderate incomes (Madura, 2008, p. 502). In principle, the CRA is/was not intended to force commercial banks to make high-risk loans per se; rather, it is/was in principle intended to help ensure that lower-income and qualified borrowers receive the loans they request/apply for.

In 1995, the Community Reinvestment Act was revised and strengthened. Indeed, the 1995 revisions were credited with helping to substantially elevate the volume of loans made to small businesses and to low- and moderate-income borrowers for home loans (Apgar \& Duda, 2003). Some part of the increase in the latter type of lending was likely attributable to increased efficiency in the secondary market for mortgage loans. Indeed, the revisions to this statute in 1995 facilitated the securitization of Community Reinvestment Act loans containing subprime mortgages. In October of 1997, First Union Capital Markets and Bear, Stearns \& Co. launched the first publicly available securitization of such loans. The securities were guaranteed by Freddie Mac and had an implied "AAA" rating.

According to Apgar \& Duda (2003), the CRA, especially after its revisions in 1995, had been rather successful in encouraging bank lending in previously "redlined areas." Nevertheless, a compelling case can be made that the CRA exposed banks to increased credit risk, which would jeopardize banks" profits and solvency, especially in the era of the sub-prime mortgage (Avery et al., 2000). Accordingly, this study hypothesizes that the CRA contributed to increased bank failures by exposing them to increased credit risk, ceteris paribus.

The FDICIA statute includes provisions (Federal Deposit Insurance Corporation [FDIC], 1995, p. 26) for “...prompt corrective action measures to be taken when an insured institution's capital falls below prescribed levels, increased examination frequency, and mandated standards for safety and soundness of real estate lending and interest rate risk management." In theory, appropriate enforcement of such provisions should lead to increased bank safety and reduced bank failures. As Cebula (1999, p. 152) observes, “...both the numbers of problem banks and bank failures have declined dramatically since the enactment of FDICIA." Hence, it is expected here that the bank failure rate was a decreasing function of FDICIA, ceteris paribus.

The RNIBA established nationwide branch banking, ostensibly to help dismantle obstructions to competition in the banking industry and to increase bank operating efficiency. RNIBA effectively removed most restrictions on interstate banking in the U.S. and permitted banks to open branches nationwide, with the goal being to enable bank operations to become more efficient by no longer requiring them to maintain separate banking companies in each state to report to bank regulators. Prior to RNIBA, banks operating in multiple states had to establish separate corporations in each state, along with separate boards of directors (Madura, 2008). Thus, an expected effect of RNIBA was greater efficiency in the banking sector, at least insofar as RNIBA would reduce operating costs of existing interstate branch facilities.

Arguably however, to the degree that this statute facilitated the ability of banks to increase the number of their bank branches across state lines and across the nation, it logically follows that the establishment of these additional new bank branches would lead to increased competition in the banking industry. In addition, of course, this pattern of increasing the number of bank branches across state lines would have led to increased construction costs (and/or increased costs associated with the acquisition of branches or facilities of other institutions) and to increased total operating costs associated with this branch bank expansion per se. With regard to expansion of the legally authorized branch banking across state lines under the RNIBA, then, it is logical to have expected both increased competition among banks on the one hand and increased costs associated with construction and/or acquisitions and operations on the other hand.

Hypothetically, then, since both increased competition on the one hand and increased total operating and other costs (such as construction or acquisition costs) associated with a larger number of bank branches due to expansion on the other hand would lead to lower profitability in the financial services industry (Barth \& Brumbaugh, 1992; Barth et al., 1992; Cebula, 1999), the RNIBA could be regarded as leading to increased bank failures over time, ceteris paribus. Ironically, then, it is hypothesized that this particular federal banking statute may well have exercised the opposite effect on the banking system than was its intention!

\section{Empirical Results}

Based on the eclectic model expressed above, this empirical study initially estimates the following:

BKFRATE $_{t}=f\left(Y_{t-1}, U_{t-1}, \operatorname{COST}_{t-1}\right.$, MORT $_{t-1}$, DEF $_{t-1}$, HOMESPC $_{t-1}$, FDICIA $_{t}$, RNIBA $\left._{t}, \mathrm{CRA}_{t}\right)$

where:

BKFRATE $_{t}=$ the percentage of commercial banks that failed, i.e., were either closed or forced to merge with another bank, during year t; 
$\mathrm{Y}_{\mathrm{t}-1}=$ the average percentage growth rate of the real GDP during year $\mathrm{t}-1$;

$\mathrm{UR}_{\mathrm{t}-1}=$ the percentage unemployment rate of the civilian labor force in year $\mathrm{t}-1$;

$\operatorname{COST}_{\mathrm{t}-1}=$ the average nominal cost of funds to commercial banks in year $\mathrm{t}-1$, expressed as a percent per annum;

$\mathrm{MORT}_{\mathrm{t}-1}=$ the average interest rate yield on new 30 year fixed-rate mortgages in year $\mathrm{t}-1$,

expressed as a percent per annum;

DEFY $_{\mathrm{t}-1}=$ the structural federal budget deficit expressed as a percent of GDP in year $\mathrm{t}-1$;

HOMESPC $_{\mathrm{t}-1}=$ the number of new home sales per capita in year $\mathrm{t}-1$;

FDICIA $_{t}=$ a dummy variable indicating whether the FDICIA (the Federal Deposit Insurance Corporation Improvement Act of 1991) was in effect in year t: FDICIA $_{t}=1$ if FDICIA was in effect in year $t$, and FDICIA $t=0$ otherwise;

$\mathrm{RNIBA}_{t}=$ a dummy variable indicating whether the Riegle-Neal Interstate Banking and Branching Efficiency Act of 1994 was in effect in year $t: \mathrm{RNIBA}_{t}=1$ if this statute was in effect in year t (i.e., for the years 1994 through 2008), and RNIBA $_{t}=0$ otherwise;

$\mathrm{CRA}_{\mathrm{t}}=$ a dummy variable indicating whether the Community Reinvestment Act was in effect in year $\mathrm{t}: \mathrm{CRA}_{\mathrm{t}}=1$ if this statute in its non-enhanced form was in effect in year $t$ (i.e., for the years from 1977 though 1994); CRAt $=2$ if this statute in its enhanced form was in effect in year $t$ (i.e., for the years 1995 through 2008); and $\mathrm{CRA}_{\mathrm{t}}=0$ otherwise.

Data sources for the non-binary variables are provided in Table 1. With the exception of the binary variables, all of the non-binary variables are lagged one year; the purpose of this lagging is to avoid issues of simultaneity and avoid questions revolving around causality. The study period runs from 1970 through 2008 . Thus, the study period includes a number of years both prior to and subsequent to the pattern of deregulation in the form of the DIDMCA (the Depository Institutions Deregulation and Monetary Control Act of 1980) and the GSDIA (the Garn-St. Germain Depository Institutions Act of 1982) statutes. In addition, by running through the year 2008, the study can be regarded as current. The ADF and PP unit root tests reveal that the variables BKFRATE, COST, MORT, and HOMESPC are all non-stationary in levels but stationary in first differences for the study period, whereas the remaining variables are all stationary in levels. Consequently, the variables BKFRATE, COST, MORT, and HOMESPC are expressed in first differences form in the estimate. For the interested reader, Table 2 contains basic descriptive statistics on the nine explanatory variables in the model.

The GARCH estimate of equation (1) is provided in Table 3, where:

terms in parentheses beneath coefficients are z-statistics, and the symbol $\Delta$ is the first-differences operator. In this estimate, all nine of the estimated coefficients exhibit the expected signs, with seven being statistically significant at the one percent level or beyond, one being statistically significant at the 2.5 percent level or beyond, and one being statistically significant at beyond the ten percent level.

As for the specific results, the estimated coefficient on the $\mathrm{Y}$ variable is negative, as hypothesized, and statistically significant at the one prevent level. Thus, it is inferred that the higher the growth rate of real GDP, the lower the bank failure rate, presumably because of the stronger economy implied by a higher $\mathrm{Y}$ and the resulting better loan performance on bank balance sheets. The coefficient on the UR variable is positive and statistically significant at the six percent level, providing evidence that the weaker the economy, in this case measured by a higher aggregate unemployment rate, the greater the bank failure rate. The estimated coefficient on the COST variable is positive, as hypothesized, and statistically significant at the one percent level, implying that the higher the cost of funds to banks, the lower the bank rate of profitability and the higher the incidence of bank failures over time. The estimated coefficient on the MORT variable is negative, as expected, and statistically significant at the one percent level, implying that banks benefited from higher interest rates charged on new 30 year fixed-rate mortgages, sufficiently to reduce the percentage of banks that failed over the 1970-2008 study period. The estimated coefficient on the HOMESPC variable is negative and statistically significant at the 2.5 percent level, indicating that the greater the magnitude of per capita new home sales, the lower the bank failure rate (Barth, 2009). Finally, the estimated coefficient on the structural budget deficit variable $(\triangle \mathrm{DEFY})$ is negative, as hypothesized, and statistically significant at the one percent level. Thus, there is evidence that higher federal government structural budget deficits acted to mitigate the bank failure rate over the study period, presumably to the extent that those deficits reflected expansionary fiscal policies.

Next, consider the initial findings for the three federal banking statutes, as summarized in Table 3 . To begin, the estimated coefficient on the FDICIA variable is negative, as hypothesized, and statistically significant at the one percent level, implying that the FDICIA legislation was effective over the study period in reducing the bank failure rate, a 
finding that is consistent with the earlier studies of the effects of FDICIA by Benston \& Kaufman (1997) and Cebula $(1996,1999)$. This finding presumably reflects effects of the kinds of FDICIA provisions broadly identified in Section II above (FDIC, 1995, esp. p. 26).

Regarding the RNIBA variable, its coefficient is positive and statistically significant at the one percent level. This finding is consistent with the hypothesis proffered above that the nationwide branch banking established under the Riegle-Neal Interstate Banking and Branching Efficiency Banking Act of 1994 may have acted to increase the degree of competition within the banking industry, thereby presumably reducing bank profitability. In addition, this statute appears to have, albeit in unanticipated and unintended ways, acted on balance also to increase bank operating and other costs associated with an increased pace of branch bank expansion, further reducing bank profitability. Over time, such reduced profitability appears to have led to an increased bank failure rate.

Finally, the estimated coefficient on the CRA variable is positive (as hypothesized) and statistically significant at the one percent level. Thus, the empirical evidence implies that the provisions of the CRA (revised/enhanced in 1995), albeit intended to reduce/eliminate redlining and to reduce/eliminate discrimination in lending, as Apgar \& Duda (2003) find it did, also exercised an unintended negative side effect. Namely, it appears that the CRA ultimately also exposed commercial banks to increased credit risk (Avery et al., 2000), which in turn manifested itself in an increased bank failure rate.

Thus, over the study period, the bank failure rate in the U.S. was an increasing function of the cost of funds and the unemployment rate, and a decreasing function of the percentage growth rate of real GDP, the federal budget deficit as a percentage of GDP, the annual rate of per capita new home sales, and the interest rate on new 30 year fixed-rate home mortgages (Amos, 1992; Barth et al., 1992; Chao \& Cebula, 1996; Loucks, 1994; Saltz, 1994; Wheelock \& Wilson, 2000). The bank failure rate also was found to be reduced as a result of implementation of provisions of the Federal Deposit Insurance Corporation Improvement Act of 1991 (Benston \& Kaufman, 1997; Cebula, 1996, 1999). Finally, the bank failure rate was found to have been elevated by both the Riegle-Neal Interstate Banking and Branching Efficiency Act of 1994 and the Community Reinvestment Act of 1977 (revised and enhanced in 1995).

As a test of the robustness and consistency of the GARCH estimate provided in Table 3, as well as an effort to gain further insights into the bank-failure determinant issue, the model is now expanded to include two additional variables: bank charge-offs (CHARGE-OFF) and a binary variable to reflect the Gramm-Leach-Blilely Act (GLB). Based on Barth, Brumbaugh \& Litan (1992) and Cebula \& Belton (1994), as well as the "conventional wisdom," greater bank charge-offs should help avert bank failures. Bank charge-offs of course are a common banking practice. Furthermore, according to Cebula (2010), the Gramm-Leach-Bliley Act should have acted to increase bank failures by exposing the banking community to increased risks. In particular, it is argued by Cebula (2010, p. 455) that the GLB Act “...exposed banks to increased risks and uncertainty in a volatile stock market and thereby inadvertently introduced an increase in the bank failure rate."

The results of the GARCH estimate of the model when expanded to include these two variables are provided in Table 4. As shown, the results in Table 4 affirm all of the findings of the GARCH estimate shown in Table 3. Indeed, the UR variable actually now becomes statistically significant at the 2.5 percent level, whereas the HOMESPC variable become statistically significant at the one percent rather than 2.5 percent level. In addition, as expected, the coefficients on the CHARGE-OFF and GLB variables are negative and positive, respectively, and both are statistically significant at beyond the seven percent level. Thus, there appears to be at least modest evidence that bank charge-offs reduced bank failures, whereas the Gramm-Leach Bliley legislation, acted to increase the rate of bank failures (Cebula, 2010, pp. 455-456).

In the interest of providing further tests of the robustness of the results and accounting for both bank actions and bank performance, two additional GARCH estimates are provided, one each in Tables 5 and 6 . After accounting for bank loans to the private sector as a percent of assets [LOANASSET $\mathrm{t}_{\mathrm{t}-2}$ ] and separately for the previous-period bank failure rate $\left[B K F R A T E_{t-2}\right]$, the fundamental results shown in Tables 3 and 4 are effectively reaffirmed.

\section{Conclusion}

This study investigates factors influencing the bank failure rate in the U.S. over the period from 1970 through 2008. For purposes of this study, a bank failure occurs when a bank is forced by regulators either to close or to merge with another banking institution. The analysis ultimately considers seven economic/financial factors and four federal banking statutes. The GARCH estimate results imply that the bank failure rate was an increasing function of the cost of funds and the unemployment rate, and a decreasing function of the percentage growth rate of real GDP, the federal budget deficit as a percentage of GDP, the rate of per capita new home sales, and the interest rate on new 30 year fixed-rate home 
mortgages (Amos, 1992; Barth et al., 1992; Chao \& Cebula, 1996; Loucks, 1994; Saltz, 1994; Wheelock \& Wilson, 2000). The bank failure rate also was found to be reduced as a result of implementation of provisions of the Federal Deposit Insurance Corporation Improvement Act of 1991 (Benston \& Kaufman, 1997; Cebula, 1996, 1999). In addition, the bank failure rate was found to have been elevated by both the Riegle-Neal Interstate Banking and Branching Efficiency Act of 1994 and the Community Reinvestment Act of 1977. Finally, there is modest evidence that increased bank charge-offs may have marginally reduced the bank failure rate (Barth et al., 1992; Cebula \& Belton, 1994) whereas the Gramm-Leach Bliley statute may have acted to increase the rate of bank failures (Cebula, 2010).

\section{References}

Amos, O. M. (1992). The regional distribution of bank closings in the United States from 1982 to 1988. Southern Economic Journal, 58, 805-115, doi:10.2307/1059846, http://dx.doi.org/10.2307/1059846

Apgar, W. C., \& Duda, M. (2003). The twenty-fifth anniversary of the Community Reinvestment Act: past accomplishments. Economic Policy Review of the Federal Reserve Bank of New York, 9, 169-191.

Avery, R. B., Bostic, R. W., \& Canner, G. B. (2000). The performance and profitability of CRA-related lending. Economic Commentary, Federal Reserve Bank of Cleveland. [Online] Available:

$\mathrm{http} / /$ www.clevelandfed.org/research/Commentary/2000/1100.htm

Barth, J.R. (1991). The great savings and loan debacle. Washington, DC: American Enterprise Institute.

Barth, J.R. (2009). The rise and fall of U.S. mortgage and credit markets. Santa Monica, CA: Milken Institute.

Barth, J. R., \& Brumbaugh, R. D. (1992). The reform of federal deposit insurance. New York: Harper Business.

Barth, J. R., Brumbaugh, R. D., \& Litan, R. E. (1992). The future of American banking, Armonk, NY: M. E. Sharpe, Inc.

Benston, G. J., \& Kaufman, G. G. (1997). FDICIA after five years. Journal of Economic Perspectives, 11, 139-158.

Bradley, M. D., \& Jansen, D. W. (1986). Deposit market deregulation and interest rates. Southern Economic Journal, 53, 478-489, doi:10.2307/1059428, http://dx.doi.org/10.2307/1059428

Cargill, T. F., \& Garcia, G. G. (1985). Financial reform in the 1980s. Stanford, CA: Hoover Press.

Cebula, R. J. (1996). An exploratory empirical analysis of the impact of FDICIA on bank failures in the United States. Applied Financial Economics, 7, 695-702. doi:10.1080/758533862, http://dx.doi.org/10.1080/758533862

Cebula, R. J. (1999). An updated evaluation of U.S. banking legislation: The Federal Deposit Insurance Corporation Improvement Act of 1991 and its performance in terms of the financial services industry. Swiss Journal of Economics and Statistics, 112, 145-164.

Cebula, R. J. (2010). Bank failures in light of the Gramm-Leach-Bliley Act. Atlantic Economic Journal, 38(4), 455-456, doi:10.1007/s11293-010-9242-2, http://dx.doi.org/10.1007/s11293-010-9242-2

Cebula, R. J., \& Belton, W. J. (1994). Failures in the financial services industry. New York: McGraw-Hill.

Cebula, R. J., Koch, J. V., \& Fenili, R. N. (2011). The bank failure rate, economic conditions, and banking statutes in the U.S., 1970-2009. Atlantic Economic Journal, 39(1), 5-16, doi:10.1007/s11293-010-9258-7, http://dx.doi.org/10.1007/s11293-010-9258-7

Chao, R. Y., \& Cebula, R. J. (1996). A heteroskedastic-TOBIT analysis of the S\&L closing problem. Journal of Financial Services Research, 10, 5-25.

Council of Economic Advisors. (2010), Economic report of the President, 2010. Washington, D.C.: U.S. Government Printing Office.

Federal Deposit Insurance Corporation. (1995). Annual report, 1995. Washington, D.C.: Author.

Federal Deposit Insurance Corporation. (2009). Annual report, 2009, Washington, D.C.: Author.

Gropp, R., Vesala, J., \& Vulpes, G. (2006). Equity and bond market signals as leading indicators of bank fragility. Journal of Money, Credit and Banking, 38, 399-428, doi:10.1353/mcb.2006.0032, http://dx.doi.org/10.1353/mcb.2006.0032

Loucks, C. (1994). The regional distribution of bank closings in the United States from 1982 to 1988: a brief note. Southern Economic Journal, 61, 191-194, doi:10.2307/1060140, http://dx.doi.org/10.2307/1060140

Madura, J. (2008). Financial markets and institutions. Mason, OH: Thompson Publishing Corp. 
Saltz, I. S. (1994). On Regulation Q and the bank failure rate in the United States. International Review of Economics and Business, 41, 185-191.

Wheelock, D., \& Wilson, P. (2000). Why do banks disappear? The determinants of U.S. bank failures and acquisitions. Review of Economics and Statistics, 82, 127-138, doi:10.1162/003465300558560, http://dx.doi.org/10.1162/003465300558560

Table 1. Descriptive Statistics

\begin{tabular}{|c|c|c|}
\hline Variable & Mean & Standard Deviation \\
\hline BKFRATE & 0.6218 & 1.05297 \\
\hline Y & 2.987 & 2.007 \\
\hline UR & 6.141 & 1.336 \\
\hline COST & 5.9464 & 2.7948 \\
\hline MORT & 8.802 & 2.35 \\
\hline HOMESPC & 0.0014 & 0.00028 \\
\hline DEFY & 2.428 & 1.911 \\
\hline FDICIA & 0.4615 & 0.505 \\
\hline RNIBA & 0.3846 & 0.493 \\
\hline CRA & 1.179 & 0.721 \\
\hline
\end{tabular}

Table 2. Data Sources for Non-Binary Variables

\begin{tabular}{|c|l|}
\hline Variable & \multicolumn{1}{|c|}{ Data Source } \\
\hline BKFRATE & FDIC, 2009 \\
\hline Y & Council of Economic Advisors, 2010, Table B-4 \\
\hline UR & Council of Economic Advisors, 2010, Table B-42 \\
\hline COST & FDIC, 2009, Table 5 \\
\hline MORT & Council of Economic Advisors, 2010, Table B-73 \\
\hline HOMESPC & $\begin{array}{l}\text { Council of Economic Advisors, 2010, Table } \\
\text { B-56 }\end{array}$ \\
\hline DEFY & Council of Economic Advisors, 2010, Table B-79 \\
\hline
\end{tabular}

Table 3. GARCH/TARCH Estimation Results: Dependent Variable, $\Delta$ BKFRATE

\begin{tabular}{|c|c|c|c|}
\hline Variable & Coefficient & z-statistic & Prob. \\
\hline $\mathrm{Y}$ & -0.0498 & -5.82 & 0.0000 \\
\hline $\mathrm{UR}$ & 0.0229 & 1.89 & 0.0587 \\
\hline$\Delta$ COST & 0.0579 & 3.65 & 0.0003 \\
\hline$\Delta$ MORT & -0.1297 & -4.59 & 0.0000 \\
\hline DEFY & -0.2934 & -2.82 & 0.0047 \\
\hline$\Delta$ HOMESPC & -1.8518 & -2.37 & 0.0180 \\
\hline FDICIA & -1.1448 & -8.34 & 0.0000 \\
\hline RNIBA & 0.7168 & 5.07 & 0.0000 \\
\hline CRA & 0.2415 & 4.57 & 0.0000 \\
\hline
\end{tabular}


Table 4. Alternative GARCH/TARCH Estimation: Dependent Variable, $\triangle$ BKFRATE

\begin{tabular}{|c|c|c|c|}
\hline Variable & Coefficient & z-statistic & Prob. \\
\hline Y & -0.0618 & -4.48 & 0.0000 \\
\hline UR & 0.0449 & 2.40 & 0.0166 \\
\hline$\Delta$ COST & 0.0544 & 2.61 & 0.0091 \\
\hline$\Delta$ MORT & -0.1811 & -2.78 & 0.0055 \\
\hline DEFY & -0.0411 & -3.63 & 0.0003 \\
\hline$\Delta$ HOMESPC & -2.4428 & -4.20 & 0.0180 \\
\hline FDICIA & -0.9873 & -8.10 & 0.0000 \\
\hline RNIBA & 0.5008 & 4.72 & 0.0000 \\
\hline CRA & 0.3265 & 6.18 & 0.0000 \\
\hline$\Delta$ CHARGE-OFF & -0.2705 & -1.84 & 0.0657 \\
\hline GLB & 0.0060 & 1.85 & 0.0640 \\
\hline
\end{tabular}

Table 5. Alternative GARCH/TARCH Estimation: Dependent Variable, $\Delta$ BKFRATE

\begin{tabular}{|c|c|c|c|}
\hline Variable & Coefficient & z-statistic & Prob. \\
\hline Y & -0.0778 & -3.03 & 0.0024 \\
\hline UR & 0.0409 & 2.62 & 0.0087 \\
\hline$\Delta$ COST & 0.0862 & 3.62 & 0.0003 \\
\hline$\Delta$ MORT & -0.3151 & -5.36 & 0.0000 \\
\hline DEFY & -0.0497 & -2.92 & 0.0035 \\
\hline HOMESPC & -2.6486 & -2.12 & 0.0342 \\
\hline FDICIA & -1.3021 & -6.88 & 0.0000 \\
\hline RNIBA & 0.5599 & 2.39 & 0.0167 \\
\hline CRA & 0.4036 & 5.05 & 0.0000 \\
\hline$\Delta$ CHARGE-OFF & -0.3338 & -2.18 & 0.0293 \\
\hline GLB & 0.0028 & 1.85 & 0.0615 \\
\hline$\Delta$ LOANASSET $_{\mathrm{t}-2}$ & 0.0002 & 4.42 & 0.0000 \\
\hline
\end{tabular}

Table 6. Alternative GARCH/TARCH Estimation: Dependent Variable, $\triangle$ BKFRATE

\begin{tabular}{|c|c|c|c|}
\hline Variable & Coefficient & z-statistic & Prob. \\
\hline Y & -0.0587 & -4.38 & 0.0000 \\
\hline UR & 0.0453 & 2.54 & 0.0110 \\
\hline$\Delta$ COST & 0.0509 & 2.04 & 0.0417 \\
\hline$\Delta$ MORT & -0.1709 & -2.70 & 0.0070 \\
\hline DEFY & -0.0485 & -4.10 & 0.0000 \\
\hline$\Delta$ HOMESPC & -2.1460 & -3.43 & 0.0006 \\
\hline FDICIA & -1.0775 & -9.07 & 0.0000 \\
\hline RNIBA & 0.5784 & 5.07 & 0.0000 \\
\hline CRA & 0.3141 & 5.42 & 0.0000 \\
\hline$\Delta$ CHARGE-OFF & -0.2501 & -1.97 & 0.0492 \\
\hline GLB & 0.0070 & 1.88 & 0.0492 \\
\hline$\Delta$ LOANASSET $_{\mathrm{t}-2}$ & -0.0095 & -0.25 & 0.8022 \\
\hline
\end{tabular}

